\title{
Identification of different laminin binding proteins in basolateral cell membranes of human colorectal carcinomas and normal colonic mucosa
}

\author{
A Stallmach, H-H Riese, D Schuppan, G Bornhöft, H Stein, E O Riecken
}

\begin{abstract}
The adhesive properties of tumour cells to laminin, the major glycoprotein of basement membranes, play a crucial part in the complex process of tumour invasion and metastasis. We therefore investigated the expression of laminin binding proteins in isolated basolateral cell membranes of human colorectal carcinomas and the adjacent normal colonic mucosa. Cell membrane binding assays and immunoblotting experiments showed appreciable quantitative and qualitative differences in the expression of these proteins in neoplastic and normal tissue. Epithelial basolateral cell membranes of colorectal carcinomas bound five to eight times more radioactive labelled laminin than basolateral cell membranes of the adjacent normal colonic epithelium. The expression of laminin binding proteins with $\mathbf{M}_{\mathbf{r}}$ 66000-69000 daltons corresponding to the so called ' $M_{r} 67000$ dalton laminin receptor' was three to four times higher in colorectal carcinomas than in normal colonic epithelium. In addition, laminin binding proteins with higher molecular weights, which may be related to the family of integrins, were also increased in colorectal carcinomas. In particular, laminin binding proteins with $M_{r} 180000$ daltons were exclusively expressed on neoplastic epithelial cells of human colorectal carcinomas. Our data suggest that certain classes of laminin binding proteins may be selectively expressed on colonic tumour cells, leading to an increased capacity for migration, invasion, and metastasis.
\end{abstract}

Carcinoma of the colon is a leading cause of death from cancer in humans. The incidence rates for colorectal cancer in Western Europe ranges from 25-40 per 100000 population with 35 per 100000 in Britain'; more than half of these patients are expected to die of this disease. ${ }^{2}$ The prognosis for cancer patients is mainly influenced by tumour growth, local infiltration, and metastasis. During the transition from in situ to invasive carcinomas normal or dysplastic epithelial cells resting on a basement membrane are replaced by tumour cells which degrade the subepithelial basement membrane of the crypts and invade the underlying stroma. To enter the circulation, metastasising tumour cells have to penetrate lymphatic walls and vascular basement membranes. Circulating tumour cells are partly arrested in the lumina of capillaries in the target organ. Finally, they penetrate the vascular basement membrane to initiate a metastatic colony. The adhesive properties of tumour cells to basement membranes are known to play a crucial part in the complex process of metastasis formation, ${ }^{3}$ and tumour cell adhesion to basement membranes has been shown to correlate with their ability to metastasise. ${ }^{+}$Basement membranes are electron-dense layers $20-100 \mathrm{~nm}$ thick, whose major known components are collagen type IV, heparan sulphate proteoglycan, nidogen, and laminin. Laminin, the major glycoprotein of basement membranes, in its intact form is composed of three chains, including the A chain (440000 daltons), B1 chain (230000 daltons), and $\mathrm{B} 2$ chain ( 210000 daltons). ${ }^{56}$ In the cross-shaped structure of laminin each of the A and B chains forms one short arm, and the remaining three chains together project down the long arm. ${ }^{78}$ Laminin has been implicated in many biological processes. With respect to carcinogenesis, including colonic cancer, laminin plays an important part in cell adhesion, mitogenesis, differentiation, and metastasis. Many of the cellular effects of laminin are believed to be mediated through integral laminin binding cell membrane proteins, and two families of laminin binding proteins have so far been identified. One of these is a group of cell membrane proteins that has a molecular mass of 65000-72000 daltons and can be found in a variety of tissues and cell lines, ${ }^{9-11}$ including a human colonic adenocarcinoma derived cell line. ${ }^{12}$ This group of laminin binding proteins, designated as the so called 'laminin receptors,' bind specifically to the pentapeptide Tyr-Ile-Gly-Ser-Arg (YIGSR), a sequence domain of the $\mathrm{B} 1$ chain of the laminin molecule. It has recently been shown that these proteins act as a link for the extracellular matrix induced differentiation of endothelial cells. ${ }^{13}$

The second group of laminin binding proteins belongs to the family of integrins. The integrins are composed of a common $\beta$ chain and one of several $\alpha$ chains. They serve as signal transducers between the extracellular matrix and components of the cytoskeleton and bind specifically to the sequence Arg-Gly-Asp (RGD). ${ }^{1+}$ This tripeptide has been found in many extracellular and plasma proteins such as fibronectin, vitronectin, collagens, and the von Willebrand factor, ${ }^{15}$ and also in the A chain of the laminin molecule. ${ }^{16}$ The inhibition of the attachment of cells to laminin by a monoclonal antibody against the integrin $\alpha_{3} \beta_{1}$, the so called 'CSAT protein' or very late antigen (human $\mathrm{VLA}_{3}$ ), indicated that this integrin acts as a laminin binding protein. Its specific interaction with laminin cannot, however, be readily shown by affinity chromatography or immunoblotting due to their low affinity for laminin. ${ }^{17} 18$ Nevertheless, another member of the integrin family, the $\alpha_{6} \beta\left(\mathrm{VLA}_{6}\right)$ 
protein, was recently found to show specific high affinity binding to laminin. ${ }^{19}$ In addition to these two groups of laminin binding proteins other cell membrane proteins with the capacity to interact with laminin were identified. For example, cell surface proteins with $M_{\mathrm{r}} 110000$ and 180000 daltons were identified in neuroblastoma glioma cells and reported to play an active part in laminin induced neurite outgrowth. ${ }^{20}$

Since little is known about the molecular interaction of epithelial colonic cells and the basement membrane via cell membrane-binding proteins during malignancy and metastasis, we have isolated these proteins from human colorectal carcinomas in an attempt to characterise them and compare their size and quantities with those of the normal colonic mucosa.

\section{Methods}

\section{PATIENTS}

Surgical specimens of primary human colorectal carcinomas and adjacent normal colonic tissues were obtained from the department of surgery at this medical centre, immediately after their removal. Samples were obtained from patients with colorectal carcinomas that showed differentiation to a high degree in five, medium degree in five, and low degree in seven cases according to the classification of Morson and Dawson. ${ }^{21}$ In undifferentiated colorectal carcinomas the epithelial cells were completely unpolarised. However, the ouabain sensitive $\mathrm{Na} / \mathrm{K}$-ATPase containing cell membrane fractions (see below) represents that part of the cell membrane which interacts with basement membranes during invasion and metastases. After extensive washing

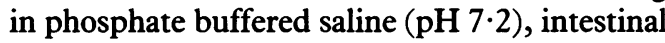
tissues were placed in liquid nitrogen.

\section{ISOLATION OF BASOLATERAL CELL MEMBRANES}

Basolateral cell membranes of human colorectal carcinomas and normal mucosa were prepared as described by Orsenigo et al. ${ }^{22}$ Briefly, mucosal scrapings were homogenised in $250 \mathrm{mM}$ sucrose, $0.1 \mathrm{mM}$ phenylmethanesulphonyl fluoride, 10 $\mathrm{mM}$ triethanolamine hydrochloride ( $\mathrm{pH} \mathrm{7 \cdot 6)}$ (buffer 1) in a Potter homogeniser on ice and centrifuged at $1000 \mathrm{~g}$ for 10 minutes. The supernatant was centrifuged for 20 minutes at $19500 \mathrm{~g}$. The fluffy white upper layer of the double pellet was resuspended in buffer 1 , to which $10 \%$ Percoll had been added. After centrifugation fo 60 minutes at $48000 \mathrm{~g}$ in a Kontron TST 25.38 fixed angle rotor, basolateral cell membranes were collected as white interfacial bands, diluted by adding a three to fourfold excess of buffer 1 , and pelleted by centrifugation at $48000 \mathrm{~g}$ for 30 minutes. The pellet was analysed for ouabain sensitive $\mathrm{Na} / \mathrm{K}$-ATPase as a marker for basolateral cell membranes according to Evans. ${ }^{23}$ Briefly, activity was determined in $770 \mu \mathrm{l}$ assay buffer containing $33 \mathrm{mM}$ Tris- $\mathrm{HCl}$, pH 7.4, $33 \mathrm{mM} \mathrm{KCl}, 3.3 \mathrm{mM} \mathrm{MgCl}_{2}$, and $110 \mathrm{mM} \mathrm{NaCl}$ to which $100 \mu \mathrm{g}$ protein of basolateral cell membranes in $200 \mu$ l buffer 1 (see above) was added. The reaction was initiated by the addition of $30 \mu \mathrm{l} 100 \mathrm{mM}$ ATP-Tris (freshly prepared) and stopped by the addition of $1 \mathrm{ml}$ $25 \%$ trichloracetic acid after 30 minutes at $37^{\circ} \mathrm{C}$. Liberated orthophosphate was determined in the supernatants after centrifugation. To obtain oubain sensitive $\mathrm{Na} / \mathrm{K}$-ATPase activity, the reaction was measured after the addition of $1 \cdot 1 \mathrm{mM}$ oubain (final concentration) to the assay buffer. The final ratio between the specific ouabain sensitive $\mathrm{Na} / \mathrm{K}$-ATPase activities of the purified basolateral cell membranes and the initial homogenates of colorectal carcinomas or normal colonic mucosa (enrichment factor) was (mean (SD)) 7.3 (2.5) and 8.4 (2.9) respectively.

\section{BINDING ASSAYS}

For binding assays intact laminin was labelled with ${ }^{125} \mathrm{I}(1 \mathrm{mCi} / 10 \mu \mathrm{g}$ antigen) using the chloramine-T method. The specific activity of labelled laminin was approximately $1-2 \times 10^{5} \mathrm{cpm} / \mathrm{ng}$ protein. Binding of ${ }^{125} \mathrm{I}$-labelled laminin to cell membranes immobilised on nitrocellulose filters was performed as described recently..$^{12}$ Briefly, purified cell membranes (10-20 $\mu \mathrm{g}$ protein) of colorectal carcinomas and the adjacent normal colonic mucosa were blotted onto nitrocellulose, and incubated in 3\% defatted cows' milk in Trisbuffer. Then the strips were incubated with laminin $\left(2-5 \times 10^{5} \mathrm{cpm}\right)$ in phosphate buffered saline containing $0.04 \%$ Tween 20 (PBS/Tween) for one hour at room temperature followed by washing three times in PBS/Tween and counting in a gammacounter.

\section{AFFINITY CHROMATOGRAPHY}

Affinity chromatography was performed basically as described elsewhere. ${ }^{24}$ Ten $\mathrm{mg}$ of laminin isolated from the EHS-sarcoma ${ }^{25}$ was coupled to CNBr-activated Sepharose 4B (Pharmacia, Uppsala, Sweden). During each run, samples of basolateral cell membranes ( $10 \mathrm{mg}$ protein content) were applied to the laminin-Sepharose column at a concentration of $0.2-0.5 \mathrm{mg} / \mathrm{ml}$ $(1 \times 6 \mathrm{~cm})$. Samples were recirculated overnight at room temperature, and elution was performed with a linear salt gradient between 0 and $3 \mathrm{M} \mathrm{NaCl}$ followed by $0.2 \mathrm{M}$ glycine $\mathrm{HCl}$, $\mathrm{pH} 2 \cdot 5$. Eluted fractions were lyophilised after extensive dialysis against phosphate buffered saline ( $\mathrm{pH} \mathrm{7 \cdot 2)}$ and then against water.

\section{POLYACRYLAMIDE GEL ELECTROPHORESIS}

Fractions obtained by affinity chromatography were analysed by sodium dodecyl sulphatepolyacrylamide gel electrophoresis in $10 \%$ gels. ${ }^{26}$ To identify laminin binding proteins, gel electrophoresed fractions were transferred to nitrocellulose according to Towbin $e t a l^{27}$ and analysed as described recently. ${ }^{12}$ Briefly, after saturation of unspecific binding sites with $3 \%$ defatted cows' milk in $20 \mathrm{mM}$ Tris- $\mathrm{HCl}$ buffer, containing $0.9 \% \mathrm{NaCl}, 20 \mathrm{mM} \mathrm{NaN}_{3}$ (pH 8.2) (Tris-buffer), nitrocellulose strips with blotted cell membranes were incubated with intact mouse tumour laminin $(1 \mu \mathrm{g} / \mathrm{ml})$ in Tris-buffer containing $0 \cdot 1 \%$ desoxycholate $(\mathrm{pH} 7 \cdot 2)$ (TrisDOC-buffer) overnight at room temperature. The strips were then washed with Tris-DOC- 
Binding of radioactive labelled laminin to isolated basolateral cell membranes from colorectal carcinomas and the adjacent normal colonic epithelium immobilised on nitrocellulose

\begin{tabular}{llll}
\hline & & \multicolumn{2}{c}{$\begin{array}{l}\text { Basolateral cell membranes (cpm/lo ng } \\
\text { protein) }\end{array}$} \\
\cline { 3 - 4 } & $\begin{array}{l}\text { Degree of tumour } \\
\text { Case no }\end{array}$ & Of carcinomas & $\begin{array}{l}\text { Of the adjacent normal } \\
\text { colonic mucosa }\end{array}$ \\
\hline 1 & High & 5950 & 950 \\
2 & High & 6310 & 1250 \\
3 & Medium & 8020 & 1610 \\
4 & Low & 9220 & 1590 \\
5 & Low & 7950 & 1600 \\
6 & Low & 7750 & 1070 \\
\hline
\end{tabular}

Degree of tumour differentiation is explained in the Methods. Values are the mean of triplicate experiments. Standard deviation was less than $10 \%$ in all experiments.

buffer and incubated overnight with antilaminin antibodies $(1 \mu \mathrm{g} / \mathrm{ml})$ at $4^{\circ} \mathrm{C}$. Bound antibodies were detected with antirabbit IgG antibodies (Janssen, Belgium) coupled to colloidal gold. The quantity and molecular weight distribution of laminin binding proteins was estimated by laser scanning densitometry.

\section{STATISTICAL ANALYSIS}

Statistical significance was calculated using the Wilcoxon rank test.

\section{Results}

BINDING OF LAMININ TO ISOLATED CELL MEMBRANES

The first evidence of the existence of specific
A

$A^{\prime}$
B

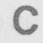

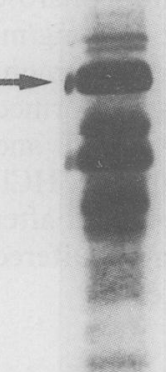
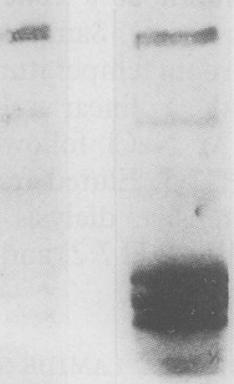

Figure 1: Identification of specific laminin binding components of basolateral cell membranes of colorectal carcinomas after fractionation on laminin sepharose and transfer of electrophoresed proteins to nitrocellulose by immunoblotting. Fractionated basolateral cell membranes: lane A, after elution with $0.2-0.3 \mathrm{M} \mathrm{Na}(\% l ; B$, after elution with $0.5 \mathrm{M} \mathrm{NaCl;C}$, after elution with $I M \mathrm{NaCl} l D$, after elution with $I \cdot 2-3 \mathrm{M} \mathrm{NaCl}$. L anes $A^{\prime}, C^{\prime}$ : negative control of transferred cell membranes to lanes $A, C$. Standards are myosin $\left(M_{r} 205 \mathrm{k} D \mathrm{D}\right)$ ), $\beta$ i galactosidase laminin binding components on the epithelial cell membrane of colorectal carcinomas and the adjacent normal mucosa was obtained from binding assays using radiolabelled laminin Basolateral cell membranes of colorectal carcinomas bound five to eight times more laminin than basolateral cell membranes of the normal colonic mucosa $(\mathrm{p}<0.01)$ (see Table). Binding of labelled laminin to isolated basolateral cell membranes from undifferentiated colorectal carcinomas was higher than binding of laminin to cell membranes of highly differentiated colorectal carcinomas. The differences were not significant. Binding of labelled laminin to isolated cell membranes was specific, since the addition of unlabelled laminin successfully inhibited the binding of the labelled molecule (data not shown).

\section{IDENTIFICATION OF LAMININ BINDING PROTEINS}

\section{IN BASOLATERAL CELL MEMBRANES OF}

COLORECETAL CARCINOMAS AND NORMAL COLONIC MUCOSA

Laminin binding components in epithelial basolateral cell membranes of colorectal carcinomas were fractionated on laminin-sepharose affinity matrix, separated on sodium dodecyl sulphatepolyacrylamide gel, transferred to nitrocellulose, and identified by immunoblotting. Elution at $0 \cdot 2-0 \cdot 3 \mathrm{M} \mathrm{NaCl}$ yielded different laminin binding components with $M_{r}$ of 75000 to 85000 , $95000,100000,120000,140000$, and 180000 daltons without reduction of disulphides. At $1 \mathrm{M} \mathrm{NaCl}$ a group of laminin binding proteins with molecular weights between 66000 and 69000 daltons was eluted, and only small amounts of proteins with $M_{r} 67000$ and 180000 daltons were obtained by a final elution with $0 \cdot 2 \mathrm{M}$ glycine $\mathrm{HCl}, \mathrm{pH} 2 \cdot 5$ (Fig 1 ).

After fractionation of basolateral cell membranes prepared from normal colonic mucosa on

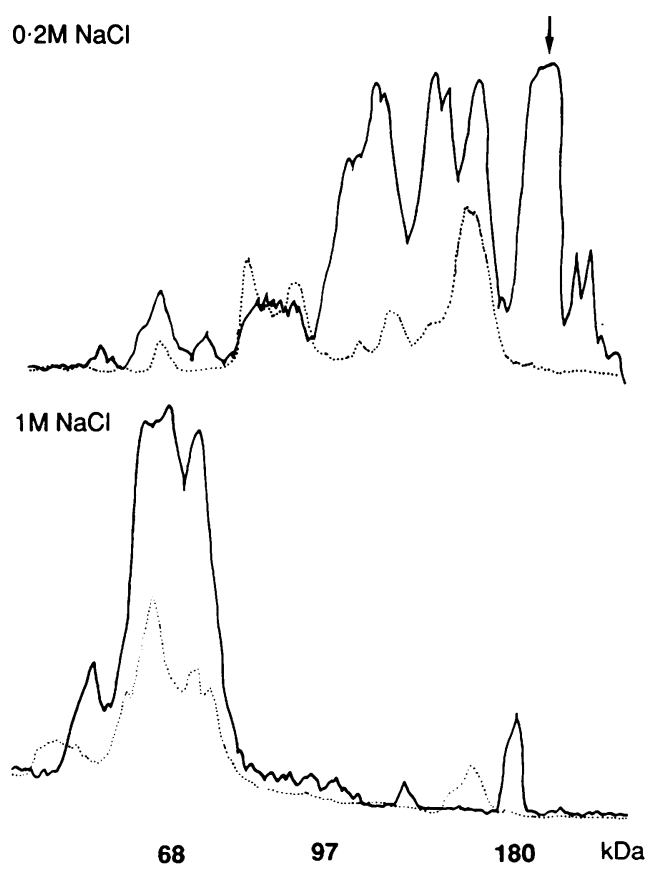

Figure 2: Densitometric analysis of specific laminin binding components in basolateral cell membranes of colorectal carcinomas (-) and normal colonic mucosa (...) after fractionation on laminin-sepharose. 
the laminin-Sepharose affinity matrix it was possible to obtain, after elution at $0 \cdot 2-0.3 \mathrm{M} \mathrm{NaCl}$, an almost identical set of laminin binding proteins with molecular weights of 75000 to $85000,95000,100000,120000$, and 140000 daltons, which lacked, however, the 180000 dalton components. Similarly, elution at $1 \mathrm{M} \mathrm{NaCl}$ yielded bands with $\mathrm{M}_{\mathrm{r}} 66000$ to 69000 daltons under non-reducing conditions.

Densitometric analysis of the bands detected by immunoblotting showed striking quantitative and qualitative differences between laminin binding proteins from normal colonic mucosa and those from colorectal carcinomas. Calculations of the relative amount of various laminin binding proteins based on an identical enrichment factor for basolateral cell membrane purifications, an equal amount of protein applied to the gels, and identical immunoblotting conditions showed that, in the tumour compared with normal colonic epithelium, expression of laminin binding proteins with $M_{r} 66000$ to 69000 daltons was three to four times higher and that of laminin binding proteins with $M_{r} 95000$ and 120000 five to eight times higher (Fig 2). Laminin binding proteins with $M_{r} 75000$ to 85000 daltons were found in similar amounts in epithelial cells of both colorectal carcinomas and normal colonic mucosa.

Interestingly, very high amounts of laminin binding protein(s) with $M_{r} 180000$ daltons were detected only in basolateral cell membranes of colorectal carcinomas (Fig 2).

\section{Discussion}

Analysis of the interaction of colonic tumour cells with the basement membrane is of major importance for understanding tumour cell invasion and metastasis formation. When cells migrate from one tissue to another they must cross the basement membranes. ${ }^{3}$ In this study we analysed the expression of laminin binding proteins in isolated basolateral cell membranes of human colorectal carcinomas and normal adjacent colonic mucosa. Our data show appreciable quantitative and qualitative differences between the expression of various laminin binding proteins by human colorectal carcinomas and normal colonic mucosa. On the basis of binding assays we have shown that the binding of epithelial cell membranes of colorectal carcinomas to radioactive labelled intact laminin were five to eight times greater than to epithelial cell membranes of the adjacent normal colonic mucosa.

On closer inspection, using laser densitometric analysis of immunoblots, we could show that the expression of laminin binding proteins with $M_{r}$ of 66 000-69000 daltons, most probably corresponding to the so-called ' 67000 dalton laminin-receptor,' is three to four times higher in colorectal carcinomas than in normal colonic epithelium. In agreement with our results, Hand et $a l,{ }^{28}$ using a monoclonal antibody, found higher levels of laminin receptors on the cell surface of colonic carcinomas than on that of benign lesions. In addition, Yow et al have recently shown that the expression of mRNA for the 67000 dalton laminin receptor is nine times greater in colon carcinomas than in adjacent normal colonic epithelium. ${ }^{29}$ Immunohistological studies on the expression of these laminin binding protein(s) along the crypt-villus axis in the murine small intestine showed that they are increased in basolateral cell membranes of enterocytes in the base of the crypt but not detectable on cells lining the mouth of the crypts and the villi. ${ }^{30}$ It is interesting that, in cryostat sections from duodenal biopsy specimens of patients with gluten sensitive sprue, an increased expression of 67000 dalton laminin receptors was observed in basolateral cell membranes of undifferentiated enterocytes in all hyperplastic crypts extending to the surface epithelium of the flattened mucosa. ${ }^{31}$ Recently, Grant et al have shown that the interaction of endothelial cells with laminin through the $M_{r} 67000$ dalton receptor induces differentiation, while laminin binding proteins of high molecuar weights which may be related to the family of integrin receptors (see below) primarily promote cell adhesion. ${ }^{13}$ If the $M_{r}$ 67000 dalton laminin receptor is an integral transmembrane protein that induces differentiation, it is not clear why epithelial cells with a high density of these proteins are undifferentiated.

In addition to the $M_{r} 66000-69000$ dalton we found laminin binding proteins with higher molecular weights in basolateral cell membranes of colorectal carcinomas and their normal counterpart. The normal colonic epithelium expresses laminin binding proteins with $M_{r} 95000,100000,120000,140000$ daltons. These proteins were also found in appreciably increased amounts on epithelial cells of colorectal carcinomas (see Fig 2). In view of their molecular weight most of these proteins may be related to the family of integrin receptors. ${ }^{1+} \mathrm{A}$ cell membrane laminin binding protein in a human glioblastoma cell line with $M_{r} 140000$ daltons after reduction was recently identified as a member of the integrin family. ${ }^{32}$ In addition, monoclonal antibodies against the $\mathrm{VLA}_{3}$ protein, a cell membrane dimer with $M_{\mathrm{r}} 135000 / 130000$ daltons, ${ }^{15}$ and the $\mathrm{VLA}_{6}$ protein, a dimer with $M_{r} 150000 / 130000$ daltons, ${ }^{19}$ inhibited attachment of cells to laminin, indicating a role of the integrins in cell-matrix interaction. Interestingly, smaller laminin binding proteins with $M_{r}$ 32000 daltons, as reported by Yow et al,, 99 could not be identified using our techniques.

Laminin, a large multifunctional molecule, influences the behaviour of many cells, including the adhesion of cells to the basement membranes and the induction of morphological changes leading to cellular differentiation. ${ }^{25}$ Separate domains of laminin with distinct biological effects have been identified. Therefore it is not surprising that several cell membrane laminin binding proteins exist. It seems that integrins, interacting with the Arg-Gly-Asp sequence in the short arm of the A chain, mediate cell adhesion to laminin, ${ }^{17}$ whereas other laminin binding proteins, like cell surface galactosyltransferase, ${ }^{33}$ interact with the E8 fragment, a major part of the long arm of the laminin molecule, and may be responsible for cell spreading. ${ }^{3+35}$

The most important finding in this study is probably the identification of laminin binding 
protein(s) with $M_{r} 180000$ daltons. This seems to be expressed exclusively on epithelial cells of human colorectal carcinomas. Since metastasising tumour cells have to attach to the extracellular matrix, preferentially to the vascular basement membrane, to induce a (clonal) proliferation in this secondary site, it has been suggested $^{3}$ that increased amounts of free laminin binding proteins on neoplastic cells facilitate this type of adhesion. It is not clear, however, why neoplastic cells with a high density of laminin binding proteins detach from the basement membrane and migrate through it .

Our data suggest that certain classes of laminin binding proteins may be selectively expressed on colonic tumour cells, leading to an increased capacity for migration, invasion, and metastasis. Little is known, however, about the functional characteristics of the different laminin binding proteins in relation to epithelial cell differentiation or dedifferentiation. Further investigations on the expression and function of these proteins during invasion and metastasis of transformed cells may give us new tools for studying or even modifying cell-matrix interactions in intestinal neoplasia.

We gratefully acknowledge the expert technical assistance of $\mathrm{Mr}$ Doris Lazar. This work was supported by grant Ri 136/123-4 of the Deutsche Forschungsgemeinschaft, Bonn-Bad Godesberg.

1 Ziegler RG, Devesa SS, Fraumeni JF. Epidemiologic patterns of colorectal cancer. In: DeVita VT, Hellmann S, Rosenberg SA, eds. Important advances in oncology. Philadelphia: Lippincott, 1986: 209-32.

2 August DA, Ottow RT, Sugarbaker PH. Clinical perspectives of human colorectal cancer metastasis. Cancer Metastasis Rev 1984; 3: 303-25.

3 Liotta LA, Rao CN, Barsky SH. Tumor invasion and the extracellular matrix. Lab Invest $1983 ; 49$ : 636-9.

4 Terranova VP, Liotta LA, Russo RG, Martin GR, Role of laminin in the attachment and metastasis of murine tumor cells. Cancer Res 1982; 42: 2265-9.

5 Timipl R, Rohde H, Robey PG, Rennard SI, Foidart JM, Martin GR. Laminin - a glycoprotein from basement Martin GR. Laminin - a glycoprotein
membranes. F Biol Chem 1979; 254: 9933-7.

6 MCarthy JB, Skubitz APN, Palm SL, Furcht LT. Metastasis inhibition of different tumor types by purified laminin fragments and a heparin-binding fragment of fibronectin f Natl Cancer Inst 1988; 80: 108-15.

7 Engel J, Odermatt E, Engel A, et al. Shapes, domain organizations and flexibility of laminin and fibronectin. Two multifunctional proteins of the extracellular matrix. $\mathcal{F} \mathrm{Mo}$ Biol 1981; 150: 97-120.

8 Palm SL, McCarthy JB, Furcht LT. Alternative model for the internal structure of laminin. Biochemistry 1985; 24: 7753-60

9 Terranova VP,Rao CN, Kalebic T, Margulies IM, Liotta LA. Laminin receptor on human breast carcinoma cells. Proc Natl Acad SciUSA 1983; 80: 444-8.

10 Malinoff HL, Wicha MS. Isolation of a cell surface receptor protein for laminin from murine fibrosarcoma cells. $\mathcal{F}$ Cell Biol 1983. 96: 1475-9.

11 Rao CN, Barsky SH, Terranova VP, Liotta LA. Isolation of a tumor cell laminin receptor. Biochem Biophys Res Commun 1983; 111: 804-8

12 Stallmach A, Schuppan D, Dax J, Hanski C, Riecken EO.
Identification of laminin binding proteins in cell membranes of a human colon adenocarcinoma cell line. Gut 1990; 31 : $70-6$

13 Grant DS, Tashiro KI, Segui-Real B, Yamada Y, Martin GR, Kleinman HK. Two different laminin domains mediate the differentiation of human endothelial cells into capillary-like structures in vitro. Cell 1989; 58: 933-43.

14 Hynes RO. Integrins: a family of cell surface receptors. Cell 1987; 48: 549-54.

15 Horwitz A, Duggan K, Greggs R, Decker C, Buck C. The cell substrate attachment (CSAT) antigen has properties of a receptor for laminin and fibronectin. $f \mathrm{Cell}$ Biol $1985 ; 101$. $2134-44$.

16 Sasaki M, Kleinman HK, Huber H, Deutzmann R, Yamada Y. Laminin, a multidomain protein. F Biol Chem 1988; 263: $16536-44$

17 Horwitz A, Duggan K, Greggs R, Decker C, Buck C. The cell substrate attachment (CSAT) antigen has properties of a receptor for laminin and fibronectin. $\mathcal{F}$ Cell Biol 1985; 101 : $2134-44$.

18 Akiyama SK, Yamada SS, Yamada KM. Characterization of a $140-\mathrm{kD}$ avian cell surface antigen as fibronectin-binding molecule. $\mathcal{F}$ Cell Biol 1986; 102: 442-8.

19 Sonnenberg A, Modderman PW, Hogervorst E. Laminin receptor on platelets is the integrin VLA-6. Nature 1988; 336: 487-9.

20 Kleinman HK, Ogle RC, Cannon FB, Little CD, Sweeny TM, Luckenbill-Edds $L$. Laminin receptors for neurite formation. Proc Natl Acad Sci USA 1988; 85: 1282-6.

21 Morson BC, Dawson IMP. Adenocarcinoma and other malignant epithelial tumours. In: Morson BC, Dawson IMP, eds. Gastrointestinal pathology. Oxford: Blackwell Scientific, 1985: 648-80.

22 Orsenigo MN, Tosco M, Esposito G, Faelli A. The basolateral membrane of rat enterocyte: its purification from brush border contamination. Anal Biochem 1985; 144: 577-83.

23 Evans WH. Preparation and characterisation of mammalian plasma membranes. In: Work TS, Work E, eds. Laboratory techniques in biochemistry and molecular biology. Amsterdam: North-Holland, 1978: 107-8.

24 von der Mark K, Risse G. Isolation and characterization of laminin receptors. Methods Enzymol 1987; 144: 490-507.

25 Hahn U, Stallmach A, Hahn EG, Riecken EO. Basement membrane components are potent promoters of rat intestinal epithelial cell differentiation in vitro. Gastroenterology 1990; 98: $322-35$.

26 Laemmli UK. Cleavage of structural proteins during the assembly of the head of bacteriophage T4. Nature $1970 ; 227$ : $680-5$

27 Towbin H, Stachlin T, Gordon J. Electrophoretic transfer of proteins from polyacrylamide gels to nitrocellulose sheets: procedure and some applications. Proc Natl Acad Sci USA 1979; 76: 4350-4

28 Hand PH, Thor A, Rao CN, Liotta L. Expression of laminin receptor in normal and carcinomatous human tissues as defined by a monoclonal antibody. Cancer Res 1985; 45: 2713-9.

29 Yow H, Wong JM, Chen HS, Lee C, Steele GD, Chen LB. Increased $\mathrm{mRNA}$ expression of a laminin-binding protein in human colon carcinoma: complete sequence of a full length cDNA encoding the protein. Proc Natl Acad Sci USA 1988; 85: 6394-8.

30 Wilson JR, Weiser MM. Rat small intestinal laminin binding proteins. Digestion 1990; 46 (suppl 2): 22-30.

31 Stallmach A, Riecken EO. Laminin-cell membrane binding proteins in small intestinal epithelial cells. Digestion 1990; 46 proteins in small

32 Gehlsen KR, Dillner L, Engvall E, Ruoslahti E. The human laminin receptor is a member of the integrin family of cell adhesion receptors. Science 1988; 241: 1228-9.

33 Runyan RB, Versalovic J, Shur BD. Functionally distinct laminin receptors mediate cell adhesion and spreading: the requirement for surface galactosyltransferase in cell spreading. 7 Cell Biol 1988; 107: 1863-71.

34 Goodman SL, Deutzmann R, von der Mark K. Two distinct cell-binding domains in laminin can independently promote non-neuronal cell adhesion and spreading. $f$ Cell Biol 1987; 105: 589-98.

35 Dillner L, Dickerson K, Manthorpe M, Ruoslahti L, Engvall E. The neurite-promoting domain of human laminin promotes attachment and induces characteristics in morphology in non-neural cells. Exp Cell Res 1988; 177: 186-98. 